\title{
PENGARUH SUMBER KARBON YANG BERBEDA UNTUK PEMBENTUKAN FLOK DAN EFEKNYA PADA PERTUMBUHAN DAN SINTASAN UDANG VANAME, Litopenaeus vannamei
}

\author{
Erlangga\#, Cut Nuraini, dan Salamah \\ Program Studi IImu Kelautan, Universitas Malikussaleh \\ Tengku Nie, Cot Rd, Reuleut Timur, Muara Batu, Kabupaten Aceh Utara, Aceh
}

(Naskah diterima: 31 Maret 2021; Revisi final: 27 Mei 2021; Disetujui publikasi: 27 Mei 2021)

\begin{abstract}
ABSTRAK
Udang vaname (Litopenaeus vannamei) merupakan spesies udang introduksi yang sudah banyak dibudidayakan di tambak di Indonesia. Permasalahan pada budidaya udang vaname di tambak dengan padat tebar tinggi dan penggunaan pakan protein tinggi adalah tingginya akumulasi residu/imbah budidaya. Salah satu cara memanfaatkan limbah budidaya yaitu sistem heterotrof dengan menggunakan teknologi bioflok dengan memanipulasi rasio perbandingan karbon nitrogen (C/N ratio) di dalam media budidaya. Penelitian ini bertujuan untuk mengevaluasi pembentukan flok pada pemeliharaan udang vaname dengan pemberian sumber karbon yang berbeda. Penelitian ini menggunakan metode eksperimental dengan rancangan acak lengkap yang terdiri atas lima perlakuan, yaitu: kontrol, molase, tepung terigu, tepung maizena, dan air tebu; masing-masing tiga ulangan. Setiap perlakuan diberikan pada wadah pemeliharaan udang vaname untuk menumbuhkan flok dengan menambahkan probiotik komersil. Analisis data yang dilakukan antara lain pertumbuhan dan sintasan udang, FCR, ukuran flok, volume flok, kandungan gizi flok, dan parameter kualitas air yang mendukung kehidupan udang vaname. Hasil penelitian menunjukkan bahwa pemberian sumber karbon berbeda memberikan pengaruh nyata terhadap pertumbuhan udang. Pemberian tepung terigu dalam pembentukan flok merupakan sumber karbon yang terbaik untuk meningkatkan pertumbuhan udang vaname dengan pertambahan bobot $0,56 \mathrm{~g}$; panjang $1,96 \mathrm{~cm}$; dan sintasan 90,67\% dengan nilai FCR 1,10; kandungan protein flok sebesar 27,15\% ukuran flok 450 mikron; dan volume flok $88 \mathrm{~mL} / \mathrm{L}$. Nilai kisaran parameter kualitas air DO 5,5-6,5 mg/L; pH 6,8-8,0; suhu $26^{\circ} \mathrm{C}-30^{\circ} \mathrm{C}$; salinitas 30-33 ppt; dan amonia 0,1-1,54 mg/L. Implikasi penelitian ini membuktikan pemberian sumber karbon memberikan pengaruh terhadap peningkatan flok dan mampu meningkatkan pertumbuhan dan sintasan udang vaname. Sebaiknya diperlukan penelitian lebih spesifik untuk mencari dosis terbaik dan maksimal dari sumber karbon tepung terigu untuk pembentukan flok, pertumbuhan, dan sintasan udang vaname.
\end{abstract}

\section{KATA KUNCl: flok; pertumbuhan; sintasan; sumber karbon; udang vaname}

ABSTRACT: Influence of different carbon sources on floc production and their effects on growth and survival of whiteleg shrimp, Litopenaeus vannamei. By: Erlangga, Cut Nuraini, and Salamah

Vannamei shrimp (Litopenaeus vannamei) is an introduced species of shrimp that has been widely farmed in brackishwater ponds in Indonesia. Vannamei shrimp farmed in ponds with high stocking density and fed with high protein feed produce large quantities of residues/waste. Reducing the waste could be achieved by using biofloc technology to manipulate the carbon nitrogen ratio $(\mathrm{C} / \mathrm{N}$ ratio) in the culture media. This study aimed to evaluate the formation of flocks grown on different carbon sources in the rearing media of vannamei shrimp. The study used an experimental method with a completely randomized design consisting of five treatments, namely: control, molasses, wheat flour, corn starch, and sugarcane juice, each with three replications. Data analysis was carried out on shrimp growth and survival, FCR, floc size, floc volume, floc nutrient content, and water quality parameters that support the life of vannamei shrimp. The results showed that different carbon sources had a significant effect on the shrimp growth. Flour is the best

\footnotetext{
\# Korespondensi: Program Studi IImu Kelautan, Universitas Malikussaleh

Tengku Nie, Cot Rd, Reuleut Timur, Muara Batu, Kabupaten

Aceh Utara, Aceh, Indonesia

E-mail: erlangga@unimal.ac.id
} 
source of carbon to support the formation of flocks which increases the growth of vannamei shrimp with a weight gain of $0.56 \mathrm{~g}$, a length of $1.96 \mathrm{~cm}$, and a survival rate of $90.67 \%$ with an FCR value of 1.10 , a floc protein content of $27.15 \%$ a floc size of 450 microns, and a floc volume of $88 \mathrm{~mL} / \mathrm{L}$. The measured variations of $\mathrm{DO}, \mathrm{pH}$, temperature, salinity, and and ammonia were $5.5-6.5 \mathrm{mg} / \mathrm{L}, 6.8-8.0,26^{\circ} \mathrm{C}-30^{\circ} \mathrm{C}, 30$ $33 \mathrm{ppt}$, and 0.1-1.54 mg/L, respectively. This research demonstrates that the provision of different carbon sources has an effect on increasing flocks and are able to increase the growth and survival of vannamei shrimp. It is recommended that more specific research is needed to find the best and maximum dose of wheat flour carbon sources for floc formation, growth and survival of vannamei shrimp.

\section{KEYWORDS: carbon; floc; growth; survival; whiteleg shrimp}

\section{PENDAHULUAN}

Budidaya udang vaname (Litopenaeus vannamei) umumnya dilakukan di tambak dengan padat tebar yang disesuaikan dengan ukuran tambak. Budidaya udang vaname di tambak dengan padat tebar tinggi dan penggunaan pakan protein tinggi menyebabkan tingginya akumulasi limbah budidaya. Oleh karena itu, diperlukan suatu sistem yang lebih efisien dalam memanfaatkan limbah budidaya. Sistem heterotrof adalah salah satu aplikasi yang diharapkan mampu mengatasi permasalahan limbah dari budidaya udang vaname dengan padat tebar yang tinggi. Pemanfaatan bakteri heterotrof berguna untuk mengonversi nitrogen anorganik menjadi organik dalam bentuk biomassa bakteri sebagai pakan tambahan bagi udang vaname.

Selain itu, teknologi bioflok mampu meningkatkan laju pertumbuhan biota yang dipelihara (ikan atau udang), meminimalisasi penggunaan pakan, mengurangi nilai $F C R$, mengurangi jumlah bakteri patogen di air dan meningkatkan kesehatan biota, serta meningkatkan tingkat sintasan biota yang dipelihara. Hal ini sesuai pendapat Gunarto et al. (2012) yang menyatakan bahwa prinsip dari teknologi bioflok adalah menumbuhkan mikroorganisme terutama bakteri heterotrof di air tambak yang dimaksudkan untuk menyerap komponen polutan, amonia yang ada di air tambak dan selanjutnya dikonversi menjadi protein bakteri dan dapat dijadikan sebagai substitusi pakan bagi udang vaname yang dibudidayakan.

Di samping itu, teknologi bioflok mampu meningkatkan kualitas air dalam kegiatan budidaya melalui penyeimbangan rasio karbon dan nitrogen dalam sistem budidaya. Pada perairan normal, ketersediaan karbon di perairan tidak mencukupi rasio $\mathrm{C} / \mathrm{N} 15$ sehingga perlu penambahan sumber karbon organik eksternal ke dalam media budidaya. Sumber karbon sangat penting untuk kehidupan bakteri pada bioflok yaitu memperbanyak pertumbuhan bakteri heterotrof yang berguna untuk mengurai bahan anorganik menjadi organik atau bahan yang merupakan racun menjadi bermanfaat kembali untuk biota yang dipelihara. Udang vaname dapat memanfaatkan bioflok sebagai makanannya (Pantjara et al., 2012).
Beberapa penelitian terdahulu menyebutkan bahwa bioflok mampu menjadi makanan bagi udang dengan kandungan nutrisi yang tinggi; oleh karena itu, perlu dilakukan penelitian sumber karbon yang berbeda dalam pembentukan flok. Tujuan penelitian ini untuk mengetahui pemebntukan flok dari sumber karbon yang berbeda untuk pertumbuhan dan sintasan udang vaname.

\section{BAHAN DAN METODE}

Metode penelitian yang digunakan adalah metode eksperimen dengan pemberian sumber karbon yang berbeda pada setiap perlakuan. Perlakuan yang digunakan adalah A (kontrol), B (karbon molase), C (karbon tepung terigu), D (karbon tepung maizena), dan $\mathrm{E}$ (karbon air tebu). Biota uji adalah benih udang vaname PL-18 sebanyak 300 ekor. Benih udang vaname tersebut dimasukkan ke dalam wadah penelitian dengan kepadatan 25 ekor/13 liter air. Udang vaname sebelum digunakan untuk penelitian terlebih dahulu dilakukan proses aklimatisasi selama satu hari. Sumber karbon yang digunakan untuk penelitian ini adalah molase dengan kadar kandungan karbon 80\% tepung terigu $75 \%$ tepung maizena $85 \%$ air tebu $75 \%$ Dengan menggunakan perhitungan sumber karbon (Salamah, 2018 dalam De Schryver et al., 2008). Rasio C/N yang digunakan pada penelitian ini adalah 15:1. Sumber karbon yang telah dihitung dan ditimbang dengan berat untuk perlakuan molase rata-rata sebesar 0,096 $\mathrm{g}$; tepung terigu $1,54 \mathrm{~g}$; tepung maizena $0,072 \mathrm{~g}$; dan air tebu 0,092 g; kemudian dicampur dengan air sebanyak $220 \mathrm{~mL}$, diaduk hingga merata kemudian ditebarkan ke dalam wadah pemeliharaan. Pemeliharaan udang vaname dilakukan selama empat minggu. Pakan yang diberikan berupa pakan buatan dengan kadar protein $45 \%$ Selama masa pemeliharaan udang vaname diberikan pakan sebanyak $5 \%$ dari bobot badan udang. Frekuensi pemberian pakan adalah tiga kali sehari, yaitu pada pukul 08.00, 12.00, dan 16.00 . Untuk seminggu sekali dalam satu hari dilakukan pemuasaan pemberian pakan, agar flok yang sudah terbentuk dapat dimanfaatkan oleh udang sebagai pakan tambahan. 


\section{Pengukuran Pertumbuhan}

Pengukuran pertumbuhan udang vaname dilakukan setiap minggu dengan mengukur keseluruhan biota uji (25 ekor). Pertumbuhan udang vaname diukur dengan menggunakan rumus (Zonneveld et al., 1991):

$$
\mathrm{L}=\mathrm{Lt}-\mathrm{Lo} \text { dan } \mathrm{W}=\mathrm{Wt}-\mathrm{Wo}_{0}
$$

di mana:

L : pertambahan panjang $(\mathrm{cm})$

W : pertambahan bobot $(\mathrm{g})$

Lt : panjang akhir (cm)

Wt : bobot akhir (g)

Lo : panjang awal $(\mathrm{cm})$

Wo : bobot awal (g)

\section{Perhitungan Sintasan}

Perhitungan sintasan dilakukan setiap minggu dengan menghitung keseluruhan jumlah udang vaname yang masih hidup pada wadah pemeliharaan. Sintasan pada udang dilakukan dengan menggunakan rumus (Goddard, 1996):

di mana:

$$
\mathrm{SR}=\frac{\mathrm{Nt}}{\mathrm{No}} \times 100
$$

SR : $\operatorname{sintasan}(\%$

$\mathrm{Nt}$ : jumlah ikan yang hidup pada akhir pemeliharaan (ekor)

No : jumlah ikan pada awal pemeliharaan (ekor)

\section{Pengukuran Tingkat Konversi Pakan}

Konversi pakan adalah salah satu perhitungan yang dapat menghubungkan laju pertumbuhan dan jumlah persentase pakan. Konversi pakan merupakan jumlah pakan (g) yang dimakan oleh udang untuk menaikkan satu gram bo bot udang. Konversi pakan dapat dihitung dengan menggunakan rumus (Goddard, 1996):

di mana:

$$
\mathrm{FCR}=\frac{\mathrm{F}}{\mathrm{Wt}-\mathrm{Wo}_{0}}
$$

FCR : konversi pakan

$\mathrm{F} \quad$ : jumlah pakan yang dikonsumsi

Wt : bobot udang pada akhir

Wo : bobot udang pada awal

\section{Pengukuran Flok}

Volume flok : diukur dengan menggunakan tabung kerucut $50 \mathrm{~mL}$ kemudian diendapkan selama 10-15 menit. Pengamatan dilakukan setiap minggu per bulan.

Rumus pengukuran volume flok menurut Avnimelech (1999):

$$
\text { Volume flok }\left(\frac{\mathrm{mL}}{\mathrm{L}}\right)=\frac{\mathrm{v} \text { endapan }}{\text { v sampel air }} \times 1000
$$

Ukuran flok: Ukuran flok diukur dalam jangka waktu seminggu sekali selama masa penelitian, dengan cara mengambil flok pada pemeliharaan udang vaname sistem bioflok lalu diamati di bawah mikroskop.

\section{Proksimat Flok}

Pengecekan proksimat flok dilakukan pada saat selesai penelitian. Adapun kandungan flok yang harus di analisis yaitu kadar air dan kadar protein dengan cara memanen flok tersebut kemudian di analisi di laboratorium.

\section{Kualitas Air}

Pengukuran kualitas air dalam penelitian ini meliputi pengukuran suhu, dissolved oxygen (DO), salinitas, dan amonia. Parameter suhu, DO, dan salinitas diukur setiap hari pada pukul 08.00 WIB dan 16.00 WIB. Parameter amonia diukur satu minggu sekali.

\section{Analisis Data}

Metode analisis statistik yang digunakan adalah metode analisis sidik ragam dengan menggunakan software SPSS. Data yang dianalisis adalah data pertumbuhan bobot dan panjang, sintasan udang, dan konversi pakan. Apabila berdasarkan hasil analisis sidik ragam menunjukkan perbedaan nyata di mana $\mathrm{F}$ hitung $>\mathrm{F}$ tabel, maka selanjutnya akan dilanjutkan dengan uji Tukey untuk mengetahui perlakuan yang terbaik antara perlakuan.

\section{HASIL DAN BAHASAN}

\section{Pertumbuhan}

Pertumbuhan bobot dan panjang udang vaname yang dipelihara dengan sumber karbon yang berbeda pada sistem bioflok dapat dilihat pada Gambar 1 dan kandungan protein dapat dilihat pada Tabel 1.

Hasil analisis sidik ragam pertumbuhan bobot udang vaname berbeda sangat nyata dengan nilai $F$ hit $(21.358)>F$ tabel 0,01 $(5,99)$ dan untuk pertumbuhan panjang tidak berbeda nyata dengan nilai $\mathrm{F}$ hit (2.479) $>\mathrm{F}$ tabel 0,05 $(3,48)$ Berdasarkan Gambar 1 dapat dilihat bahwa pertumbuhan bobot dan panjang tertinggi berdasarkan uji lanjut terdapat pada perlakuan C (tepung terigu) yaitu $0,56 \mathrm{~g}$ dan $1,94 \mathrm{~cm}$. Hal ini karena pada perlakuan $\mathrm{C}$, flok tumbuh sangat baik dan jumlah protein dalam flok setelah dilakukan uji proksima yaitu $27,15 \%$ sehingga flok dapat dimanfaatkan dengan baik oleh udang. Mikroba dalam flok dapat digunakan sebagai pakan karena mengandung nutrien yang tinggi seperti protein dan nutrisi lainnya (Salamah, 2018). Hal ini sesuai dengan pendapat Firdaus (2012) bahwa komposisi mikroba dan sumber karbon yang diberikan dalam penyusun 

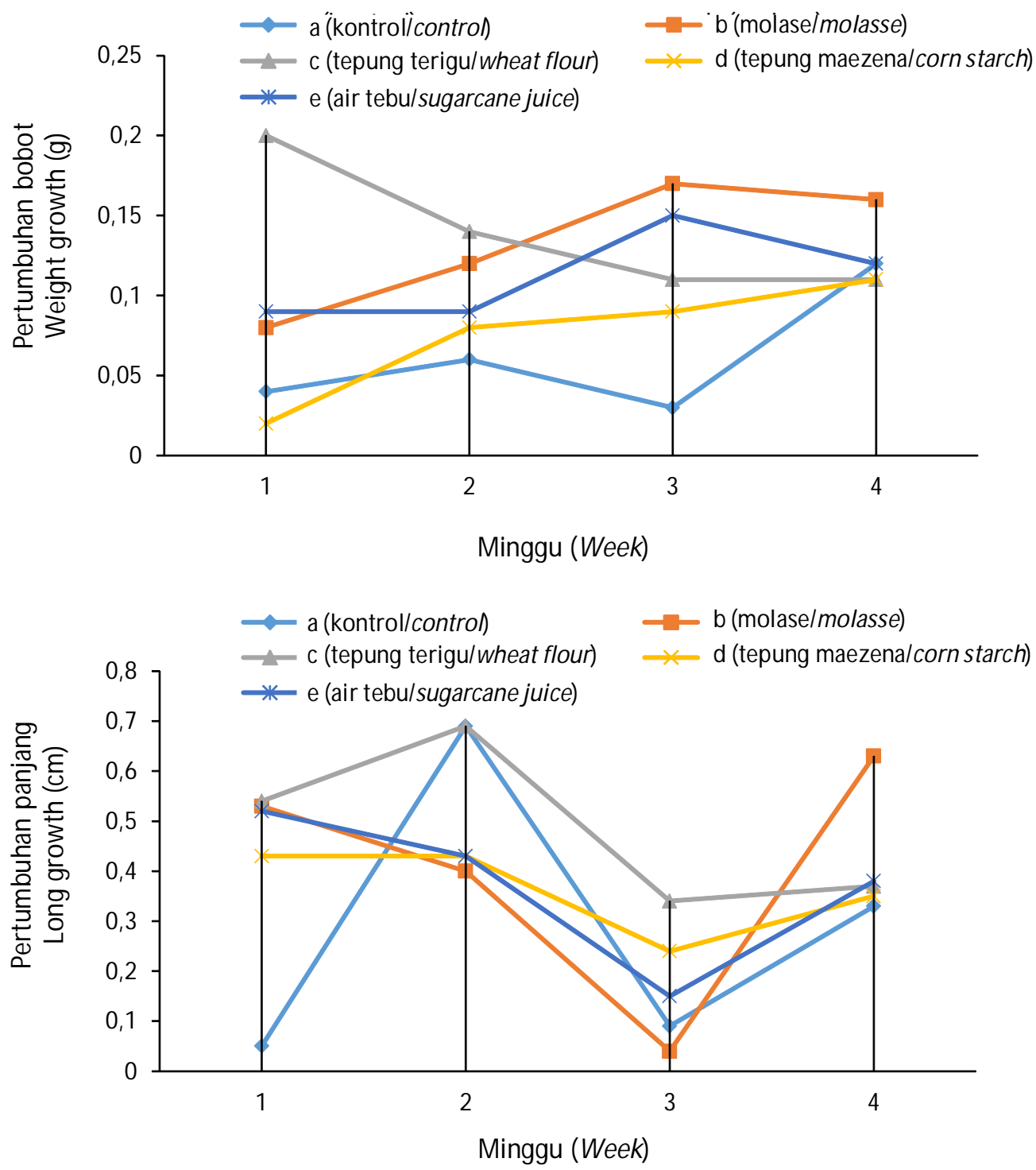

Gambar 1. Pertumbuhan bobot dan panjang udang vaname yang dipelihara dalam sistem flok dengan sumber karbon berbeda.

Figure 1. Growth of weight and length of whiteleg shrimp reared in floc systems with different carbon sources.

Tabel 1. Kandungan protein dalam flok dari sumber karbon berbeda pada budidaya udangvaname

Table 1. Protein content in flocks grown on different carbon sources

\begin{tabular}{lcc}
\hline \multicolumn{1}{c}{$\begin{array}{c}\text { Perlakuan } \\
\text { Treatments }\end{array}$} & $\begin{array}{c}\text { Kadar air } \\
\text { Moisture }(\%)\end{array}$ & $\begin{array}{c}\text { Kadar protein } \\
\text { Protein content } \mathbf{( \% )}\end{array}$ \\
\hline Molase (Molasse) & 12,31 & 23,23 \\
Tepung terigu (Wheat flour ) & 11,16 & 27,15 \\
Tepung maizena (Corn starch) & 14,06 & 18,78 \\
Air tebu (Sugarcane juice) & 14,01 & 22,84 \\
\hline
\end{tabular}


bioflok akan menentukan kandungan nutrisi flok yang diperlukan untuk menguntungkan inang dan dapat dimanfaatkan oleh udang untuk pertumbuhannya. Suprapto \& Samtafsir (2013) juga berpendapat dengan penambahan sumber karbon C/N 15:1 dapat mengontrol kualitas air dan menyediakan pakan tambahan sehingga pertumbuhannya tinggi dan lebih cepat. Bakteri mengandung protein tinggi sehingga dapat berfungsi sebagai pakan tambahan. Bakteri Bacillus sp. juga dapat menghasilkan daya cerna makanan dalam usus udang sehingga mudah diserap oleh udang. Bakteri Bacillus sp. Dapat hidup dalam usus dan menghasilkan enzim yang dapat membantu proses pencernaan, bakteri Bacillus sp. juga dapat menekan bakteri yang merugikan dalam pencernaan dengan cara melalui persaingan tempat penempelan. Firdaus (2012) menyatakan bahwa komposisi mikroba penyusun bioflok yang akan menentukan kandungan nutrisi flok. Pertumbuhan udang vaname dengan perlakuan penambahan sumber karbohidrat cenderung lebih baik dibanding dengan tanpa penambahan sumber karbohidrat. Suwoyo \& Tampangallo (2015) menyimpulkan adanya penambahan sumber karbon ke dalam media pemeliharaan udang vaname menyebabkan peningkatan populasi bakteri pembentuk bioflok.

\section{Sintasan}

Dari hasil penelitian selama satu bulan (4 minggu), sintasan udang vaname tertinggi didapatkan pada perlakuan C (tepungterigu) yaitu 90,67\% (Gambar 2). Tepung terigu sebagai sumber karbon dalam pembentukan bioflok sanqat baik denqan kandunqan gizi yang tinggi dan tekstur dari tepung terigu tidak merusak kualitas air atau proses penggumpulan tepung terigu sempurna sehinggabisa dimanfaatkan bakteri probiotik. Hasil analisis sidik ragam sintasan udang vaname berbeda sangat nyata dengan nilai $F$ hit (10.042) > F tabel 0,01 $(5,99)$

Sintasan udang vaname dipengaruhi oleh sistem imun, kualitas, air serta pakan. Hal ini sesuai pendapat Suprapto \& Samtafsir (2013), bioflok dalam media pemeliharaan mengandung probiotik, seperti yang diketahui bahwa salah satu fungsi probiotik yaitu meningkatkan sistem imun ikan dan juga kualitas air dapat terjaga. Fidyandini et al. (2016), Salah satu fungsi probiotik yaitu meningkatkan sistem imun dan juga meningkatkan kualitas air media budidaya.

Bioflok dapat dimanfaatkan sebagai sumber pakan tambahan sehingga memberikan pengaruh positif terhadap sintasan budidaya udang vaname. Hal ini sesuai dengan pendapat Fitria (2012) yang menyatakan bahwa sintasan udang sangat ditentukan oleh tersedianya makanan yang baik sehingga organisme mampu memanfaatkan pakan yang tersedia.

\section{Tingkat Konversi Pakan}

Hasil penelitian menunjukkan bahwa sumber karbon yang berbeda pada sistem bioflok memberikan hasil konversi pakan benih udang vaname lebih rendah daripada kontrol (Gambar 4). FCR terendah diperoleh pada perlakuan tepung terigu. Hasil analisis sidik ragam nilai $F C R$ udang vaname berbeda sangat nyata dengan nilai $F$ hit $(19.983)>F$ tabel $0,01(5,99)$.

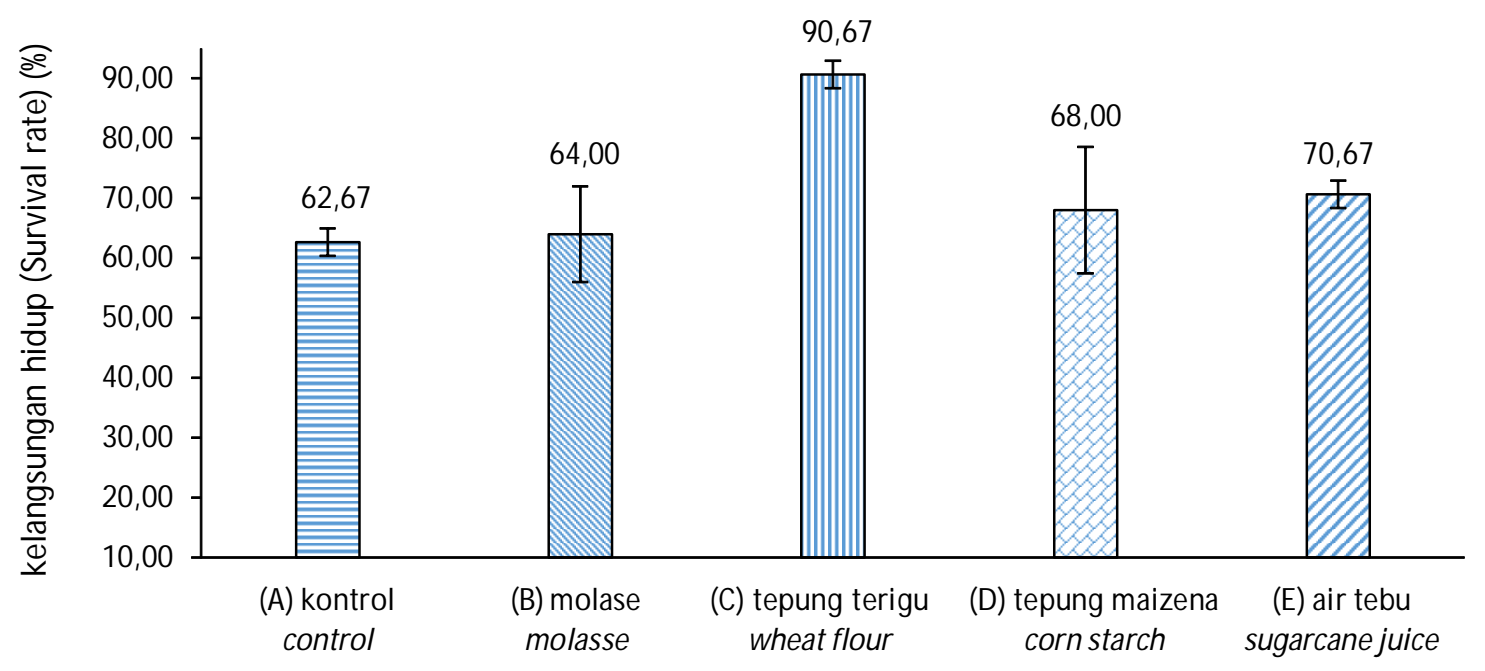

Perlakuan (Treatment)

Gambar 2. Sintasan udang vaname yang dipelihara empat minggu pada sistem flok dengan sumber karbon berbeda.

Figure 2. The survival rate of whiteleg shrimp reared for four weeks in floc systems with different carbon sources. 


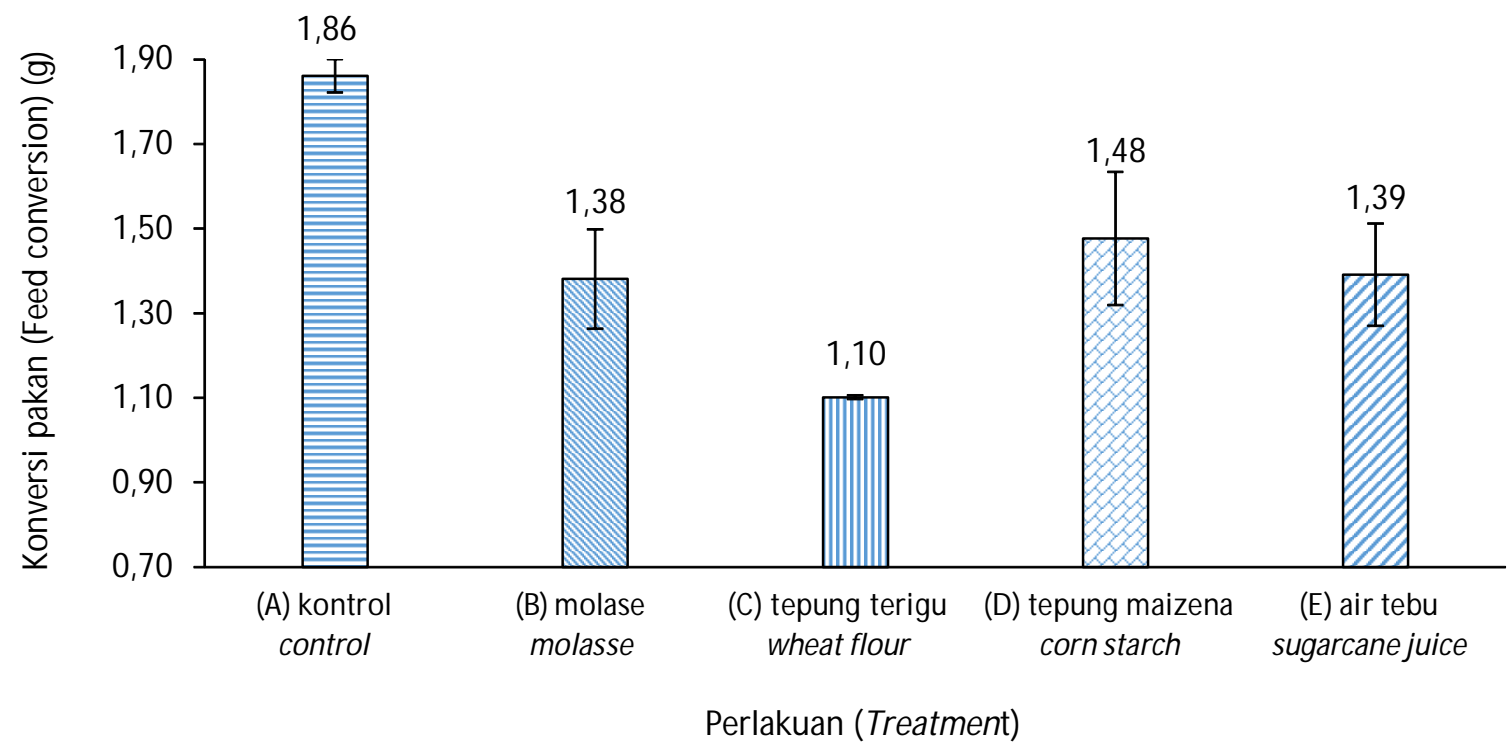

Gambar 3. Konversi pakan (FCR) udang vaname yang dipelihara dalam sistem flok dengan sumber karbon berbeda.

Figure 3. Feed convertion ratio of whiteleg shrimp reared in flock systems with different carbon sources.

Hasil penelitian menunjukkan bahwa konversi pakan terbaik pada perlakuan C (tepung terigu) yaitu sebesar 1,10. Hal ini sesuai dengan pernyataan Tahe et al. (2014) maksimal nilai rasio konversi pakan terhadap udang vaname yaitu sebesar 1,50. Konversi pakan yang baik disebabkan karena pakan yang diberikan mampu dimanfaatkan dengan baik oleh udang, dalam media bioflok adanya peran bakteri untuk mengurai bahan anorganik menjadi organik yang bisa dimanfaatkan kembali oleh udang sebagai pakan tambahan. Seperti pendapat Suprapto \& Samtafsir (2013), bahwa bakteri pembentuk flok akan mengurai bahan organik (protein, karbohdirat, lemak, dan lainlain) yang berasal dari sisa pakan, kotoran ikan, dan jasad yang mati dalam kolam sehingga dapat dimanfaatkan oleh udang sebagai pakan tambahan. Bioflok juga mengandung protein tinggi sehingga dapat dimanfaatkan oleh udang, jumlah protein yang terkandung dalam flok adalah sebesar $27,15 \%$

\section{Flok}

Berdasarkan Gambar 4 dapat dilihat bahwa kepadatan flok masing-masing perlakuan berbeda. Kepadatan flok tertinggi terdapat pada perlakuan $\mathrm{C}$ (tepung terigu) yaitu $88 \mathrm{~mL} / \mathrm{L}$, diikuti oleh perlakuan B (molase) $75 \mathrm{mg} / \mathrm{L}, \mathrm{E}$ (air tebu) $68 \mathrm{~mL} / \mathrm{L}$, D (tepung maizena) $53 \mathrm{~mL} / \mathrm{L}$, dan A sebagai kontrol $0 \mathrm{~mL} / \mathrm{L}$. Hasil analisis sidik ragam kepadatan flok tidak berbeda dengan nilai $F$ hit $(2.116)>F$ tabel $0,05(4,06)$. Hal ini terjadi karena masing-masing karbon mempunyai kecepatan reaksi tertentu. Tepung terigu, molase, dan air tebu memiliki reaksi relatif cepat untuk membentuk flok dikarenakan mudah terlarut ke dalam air, dibandingkan tepung maizena yang relatif lebih lama untuk pemecahan dan penggunaannya dikarenakan tepung maizena memiliki tekstur yang menggumpal dan lengket ketika dicampur dengan air. Tingginya nilai volume flok menggambarkan kemampuan bakteri dalam membentuk bioflok (Salamah, 2018).

Ukuran flok pada akhir penelitian yaitu pada perlakuan C (tepung terigu) ukuran floknya adalah 450 mikron, perlakuan B (molase) 300 mikron, perlakuan E (air tebu) 200 mikron, dan pada perlakuan D (tepung maizena) memiliki ukuran flok yaitu 100 mikron (Gambar 5). Flok mulai berkembang biak ditandai dengan adanya buih di permukaan air dan warna air pada media pemeliharaan berubah menjadi kuning kecoklatan, Ukuran flok juga sangat dipengaruhi oleh besarnya pengadukan dan sumber karbon yang digunakan, pengadukan air yang lebih kencang akan menyebabkan formasi flok yang terbentuk menjadi lebih kecil dibandingkan dengan pengadukan air yang lebih pelan (Suprapto \& Samtafsir, 2013).

Ukuran flok sangat berpengaruh terhadap $\mathrm{C} / \mathrm{N}$ rasio pada media bioflok, semakin bagus sumber karbon yang diberi maka semakin besar dalam pembentukan flok. Penambahan jumlah volume flok juga butuh ketersediaan yang cukupakan kadar oksigen terlarut dalam air. Hal ini sangat berkaitan dengan pendapat Suprapto \& Samtafsir (2013), menyatakan bahwa 


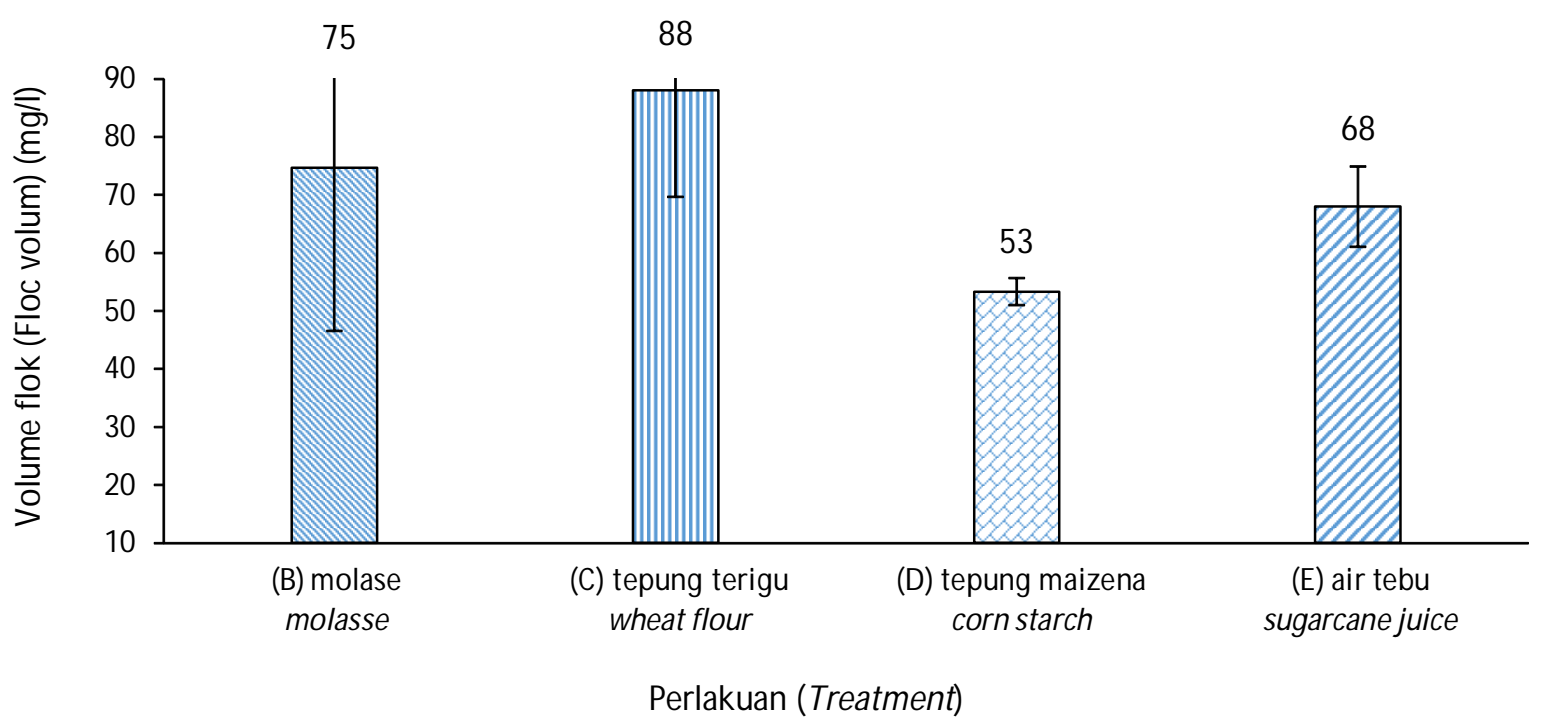

Gambar 4. Volume flok dalam budidaya udang vaname dengan sumber karbon berbeda.

Figure 4. Floc volume grown with different carbon sources in the rearing media of whiteleg shrimp.

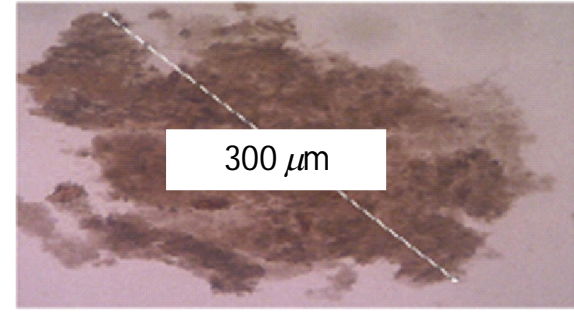

B

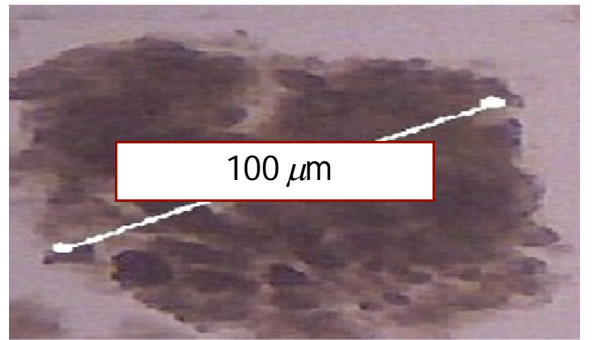

D

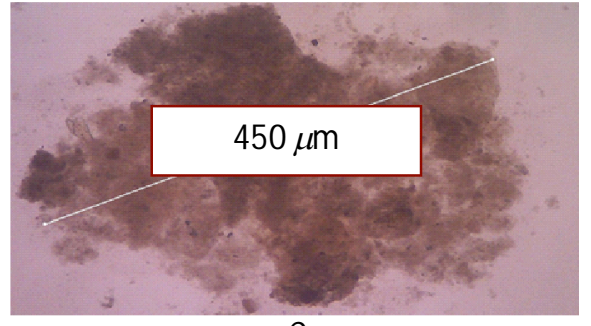

C

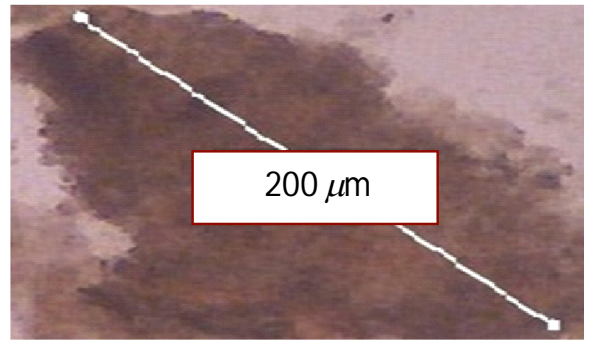

E

Gambar 5. Ukuran flok pada budidaya udang vaname dengan sumber karbon berbeda.

Figure 5. Floc size in whiteleg shrimp culture with different carbon sources.

bakteri pembentuk flok, akan mengurai bahan organik (protein, karbohidrat, lemak, dan lain-lain) yang berasal dari sisa pakan, kotoran ikan, dan jasad yang mati di dalam kolam. Purnomo (2012) peningkatan bakteri terjadi saat penambahan sumber karbon ke dalam media. Agustina (2015) menyatakan bahwa komunitas bakteri probiotik yang terakumulasi di dalam sistem akuakultur heterotrofik akan membentuk flok (gumpalan) yang dapat dimanfaatkan sebagai sumber pakan untuk udang.

\section{Kualitas Air}

Kisaran kualitas air selama penelitian menunjukkan bahwa parameter kualitas air sangat mendukung kehidupan udang vaname. Nilai parameter kualitas air dapat dilihat pada Tabel 2.

Berdasarkan kisaran kualitas air pada pemeliharaan udang vaname (L. vannamei) dengan teknologi bioflok berada pada kisaran yang baik untuk pertumbuhan udang vaname. Pada kolam bioflok kualitas air 
Pengaruh sumber karbon yang berbeda untuk pembentukan ..... (Erlangga)

Tabel 2. Parameter kualitas air budidaya udang vaname sistem flok dengan sumber karbon berbeda Table 2. Water quality parameters of white shrimp culture with floc systems with different carbon sources

\begin{tabular}{lcccccc}
\hline \multirow{2}{*}{$\begin{array}{c}\text { Parameter kualitas air } \\
\text { Water quality parameters }\end{array}$} & \multirow{2}{*}{$\begin{array}{c}\text { Waktu } \\
\text { Time }\end{array}$} & \multicolumn{5}{c}{ Perlakuan (Treatments) } \\
\cline { 3 - 7 } & & A & B & C & D & E \\
\hline Oksigen terlarut & Pagi (Morning ) & $5.0-6.4$ & $5.0-6.5$ & $5.2-6.0$ & $5.2-6.5$ & $5.3-6.3$ \\
Dissolved oxygen (mg/L) & Sore (Afternoon) & $5.5-6.1$ & $5.5-6.3$ & $5.0-6.0$ & $5.2-6.2$ & $5.5-6.3$ \\
\cline { 2 - 7 } & Pagi (Morning ) & $6.8-7.3$ & $6.8-8.0$ & $6.8-7.3$ & $6.8-8.0$ & $6.8-7.3$ \\
pH & Sore (Afternoon) & $6.7-7.1$ & $6.9-7.8$ & $6.9-7.3$ & $6.9-7.3$ & $6.9-7.3$ \\
\cline { 2 - 7 } Suhu & Pagi (Morning ) & $26-29$ & $26-29$ & $26-28$ & $26-29$ & $26-28$ \\
Temperature ('C) & Sore (Afternoon) & $26-30$ & $26-30$ & $26-29$ & $26-29$ & $26-29$ \\
\cline { 2 - 7 } Salinitas (Salinity) (ppt) & & $30-33$ & $30-33$ & $30-33$ & $30-33$ & $30-33$ \\
Amonia (Ammonia) (mg/L) & & $00.1-2.21$ & $00.1-1.54$ & $00.1-1.12$ & $00.1-1.45$ & $0.01-1.34$ \\
\hline
\end{tabular}

Keterangan (Note): $\quad A$ (kontrol/control); B (molase/molasse); C (tepung terigu/wheat flour); D (tepung maizena/corn starch); $\mathrm{E}$ (air tebu/sugarcane juice)

cenderung stabil walau tanpa pergantian air hal ini karena adanya sel bakteri dalam mengakumulasi amonia (Salamah, 2018). Semakin tingginya suhu, flok yang terbentuk semakin besar (Suprapto \& Samtafsir, 2013). Salinitas sangat berpengaruh terhadap proses metabolisme dan sintasan udang vaname. Salinitas yang didapatkan pada saat penelitian adalah berkisar 30-33 ppt, di mana kisaran tersebut layak untuk pertumbuhan dan kehidupan udang vaname. Kadar amonia selama penelitian ini sesuai dengan kehidupan udang vaname, nilai amonia berkisar antara 00,1-1,54 $\mathrm{mg} / \mathrm{L}$ masih berada pada kisaran yang baik untuk pertumbuhan udang vaname. Menurut Suprapto \& Samtafsir (2013), bahwa amonia diubah oleh bakteri heterotrof menjadi protein sel mikroba, sehingga pada akhir penelitian kandungan nilai amonia menurun. Budidaya udang vaname dengan penambahan sumber karbohidrat atau sistem bioflok dapat memperbaiki parameter kualitas air (Adipu, 2019).

\section{KESIMPULAN}

Berdasarkan hasil penelitian dan uji statistik bahwa sumber karbon yang terbaik bersumber dari tepung terigu dibandingkan sumber karbon molase, tepung maizena, dan air tebu. Hal ini terbukti dari nilai pertambahan bobot 0,56 g; panjang $1,96 \mathrm{~cm}$; dan sintasan 90,67\% dengan nilai FCR 1,10; kandungan protein flok sebesar 27,15\% ukuran flok 450 mikron; dan volume flok $88 \mathrm{~mL} / \mathrm{L}$. Nilai kisaran parameter kualitas air DO 5,5-6,5 mg/L; pH 6,8-8,0; suhu $26^{\circ} \mathrm{C}$ $30^{\circ} \mathrm{C}$; salinitas 30-33 ppt; dan amonia 0,1-1,54 mg/L. Implikasi penelitian ini membuktikan pemberian sumber karbon memberikan pengaruh terhadap peningkatan flok dan mampu meningkatkan pertumbuhan dan sintasan udang vaname. Sebaiknya diperlukan penelitian lebih spesifik untuk mencari dosis terbaik dan maksimal dari sumber karbon tepung terigu untuk pembentukan flok, pertumbuhan, dan sintasan udang vaname.

\section{UCAPAN TERIMA KASIH}

Terima kasih diucapkan kepada seluruh tim peneliti dan penulis yang telah membantu menghasilkan karya tulis ini dan terim kasih di ucapkan kepada Tim pengelola Jurnal Riset Akuakultur yang telah bersedia dan menerima hasil tulisan kami.

\section{DAFTAR ACUAN}

Adipu, Y. (2019). Profil kualitas air pada budidaya udang vannamei (Litopaneus vannamei) sistem bioflok dengan sumber karbohidrat gula aren. Jurnal MIPA, 8(3), 122.

Agustina, R.L, Hudaibah, S ., \& Supono. (2015). Keragaan udang putih (Litopenaeus vannmaei) pada densitas yang berbeda dengan sistem bioflok pada fase pendederan. e-jurnal Rekayasa dan Teknologi Budidaya perairan, 3(2), 397-402.

Avnimelech, Y. (1999). C/N Ratio as a Control Element in Aquaculture System. Aquaculture, 176(3), 227235.

Fidyandini, H.P., Yuhana, M., \& Lusiastuti, A.M. (2016). Pemberian probiotik multi spesies dalam media budidaya ikan lele dumbo untuk mencegah penyakit motile aeromonas septicemia. Jurnal Veteriner, 17(3), 440-448. 
Firdaus, R. (2012). Seleksi bakteri kandidat probiotik untuk penghambatan patogen Streptococcus agalactiae tipe non-homolotik pada ikan nila, Oreochromis niloticus secara in vitro dan in vivo. Skripsi. Institut pertanian Bogor.

Fitria, A.S. (2012). Analisis kelulushidupan dan pertumbuhan benih ikan nila (Oreochromis niloticus) F5 D30-D70 pada berbagai salinitas. Journal of Aquaculture Management and Technology, 1(1), 18-34.

Goddard, S. (1996). Feed management in intensive aquaculture. New york: Chapmen and Hal.

Gunarto, Suwoyo, H.S., \& Tampangallo, B.R. (2012). Budidaya udang vaname pola intensif dengan sistem bioflok di tambak. Jurnal Riset Akuakultur, 6(7), 393-405.

Pantjara, B., Nawang, A., Usman, \& Rachman Syah. (2012). Pemanfaatan bioflok pada budidaya udang vaname (Litopenaeus vannamei) intensif. Jurnal Riset Akuakultur, 6(7), 61-72.

Purnomo, P.D. (2012). Pengaruh penambahan karbohidrat pada media pemeliharaan terhadap produksi budidaya intensif nila (Oreochromis niloticus). Journal of Aquaculture Managemen dan Technology, hlm. 161-179.

Salamah. (2018). Penerapan teknologi bioflok pada budidaya ikan lele. Aceh: CV. Sefa Bumi Persada.

Suprapto, N.S. \& Samtafsir, L.S. (2013). Rahasia sukses teknologi budidaya lele hemat, hemat air, hemat pakan, lebih bersih $\&$ non residu, serta kualitas daging lebih baik. Jawa Barat: Bioflok-165, Agro 165.

Suwoyo, H.S. \& Tampangallo, B.R. (2015). Perkembangan populasi bakteri pada media budidaya udang vaname (Litopeneus vannamei) dengan penambahan sumber karbon berbeda.Octopus Jurnal IImu Perikanan, 4(1), 365-374.

Tahe, S., Mengampa, M., \& Makmur. (2014). Kinerja budidaya udang vaname (Litopenaeus vannamei) pola super intensif dan analisis biaya. Prosiding Forum Inovasi Teknologi Akuakultur, hlm. 23-30.

Zonneveld, N., Huisman E.A., \& Boon, J.H. (1991). Prinsip-prinsip budidaya ikan. Jakarta: Gramedia Pustaka Utama. 